\title{
Chlorophyll in Citron (Citrus medica L.)'
}

\author{
L. E. Cancel, Milagros R. de Montalvo, and Jose M. Rivera ${ }^{3}$
}

\section{INTRODUCTION}

An old but convenient method used to classify natural coloring matters is based on their solubility in different solvents. Citrus fruits contain four groups of coloring mater; the chlorophylls and carotenoids which are soluble in fat solvents, and the flavonoids and anthocyanins which are soluble in water. Chlorophylls and carotenoids are found abundantly in the epicarp (flavedo) of the fruit and in lesser amounts in the mesocarp (albedo) (4). The color pattern of unripe fruit is strikingly different from that of fruit when ripe. The amount of chlorophyll present in the green tissue masks the carotenoid content of the green fruit. As the citrus fruit undergoes ripening, the chlorophyll content diminishes while the carotenoids may increase or remain at the same level (7).

In citron, the important pigment is chlorophyll which imparts the greenish tint found in the candied product. The greenish tint in candied citron is an index of good quality.

No information has been found in the literature concerning the chlorophyll content of fresh citron, its distribution in the fruit, or the changes in its concentration during development and ripening stages. An investigation of these factors thus was conducted and the results are presented in this report.

\section{MATERIALS AND METHODS}

Citrons at different stages of maturity were obtained from a commercial farm in Adjuntas, Puerto Rico. They were harvested the day before processing and stored in a refrigerator at $45^{\circ} \mathrm{F} .\left(7.0^{\circ} \mathrm{C}\right.$.) for about 20 hours. Four stages of maturity were selected: immature green, mature green, turning ripe, and ripe. Care was taken in all cases to assure representative sampling. Ripe fruits selected were completely yellow, assuring total ripeness. Turning ripe fruits were selected about one-fourth ripe. The size of the fruits in the two samples was 5 inches by 8 inches (diameter). Mature green fruits selected were fully developed and green in color and without surface indication of possible ripening. These fruits were about 4 inches by 6 inches. Immature fruit was small and totally green, and about 2 inches by 5 inches in size.

1 Manuscript submitted to Editorial Board November 5, 1971.

2 Food Scientist and Research Assistants, respectively, Food Technology Laboratory, Agricultural Experiment Station, Mayagiiez Campus, University of Puerto Rico, Río Piedras, P.R. 
For checking the difference in maturity between immature green and mature green fruits, they were sliced in halves and the compositon of the endocarp examined for undeveloped seeds and juice sacs. The endocarp of immature green fruits was of a greenish tint, of mature green fruits greenish yellow, of turning ripe fruits completely yellow and of ripe fruits yellowish white or cream.

The selected fruits were washed, dried, and weighed before skinning and after the removal of each tissue layer. The fruits were wholly skinned with a sharp potato peeler, taking precaution to avoid overlapping. This operation

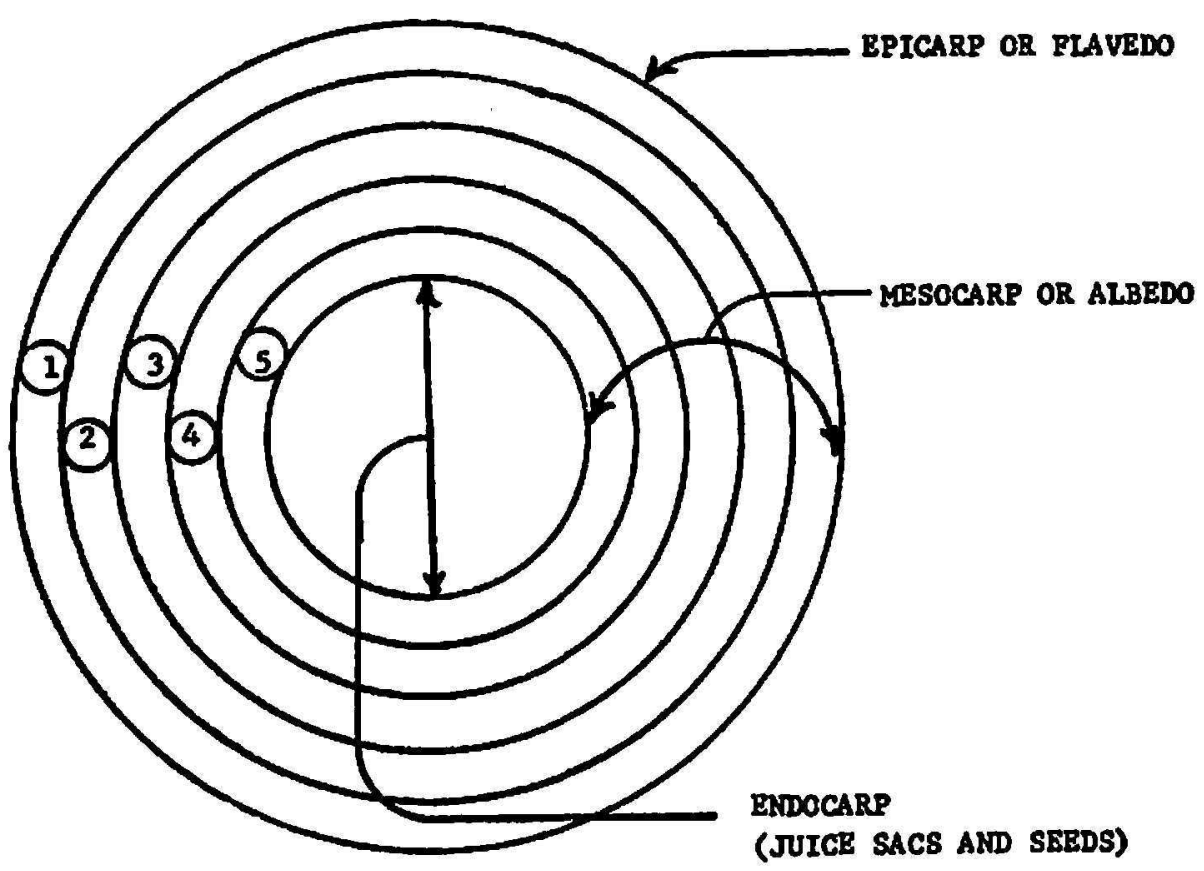

Fia. 1.-Diagram of tissue layers removed from the fruit for chlorophyll measurements. Layers are referred to in the text by the numbers here indicated.

was repeated until five separate layers of material were obtained from progressive depths of the fruit as shown in figure 1.

Each layer was about 1116 inch thick. The material representing each layer was weighed and separated for sampling.

The tissue representing each fruit layer was ground in a high-speed liquifier. A sample from the mashed pulp was weighed for spectrophotometric purposes. The weighed sample was placed in $2 \mathrm{ml}$. of acetone per $\mathrm{g}$. of tissue, as recommended by Ting and Hendrick (8). Pigment was extracted for 20 minutes under magnetic stirring to increase pigment solubilization by the extracting solvent. The acetone extract thus obtained was filtered through glass wool to remove suspended particles. An aliquot was measured for spectrophotometric reading just after completing the extracted volume to 

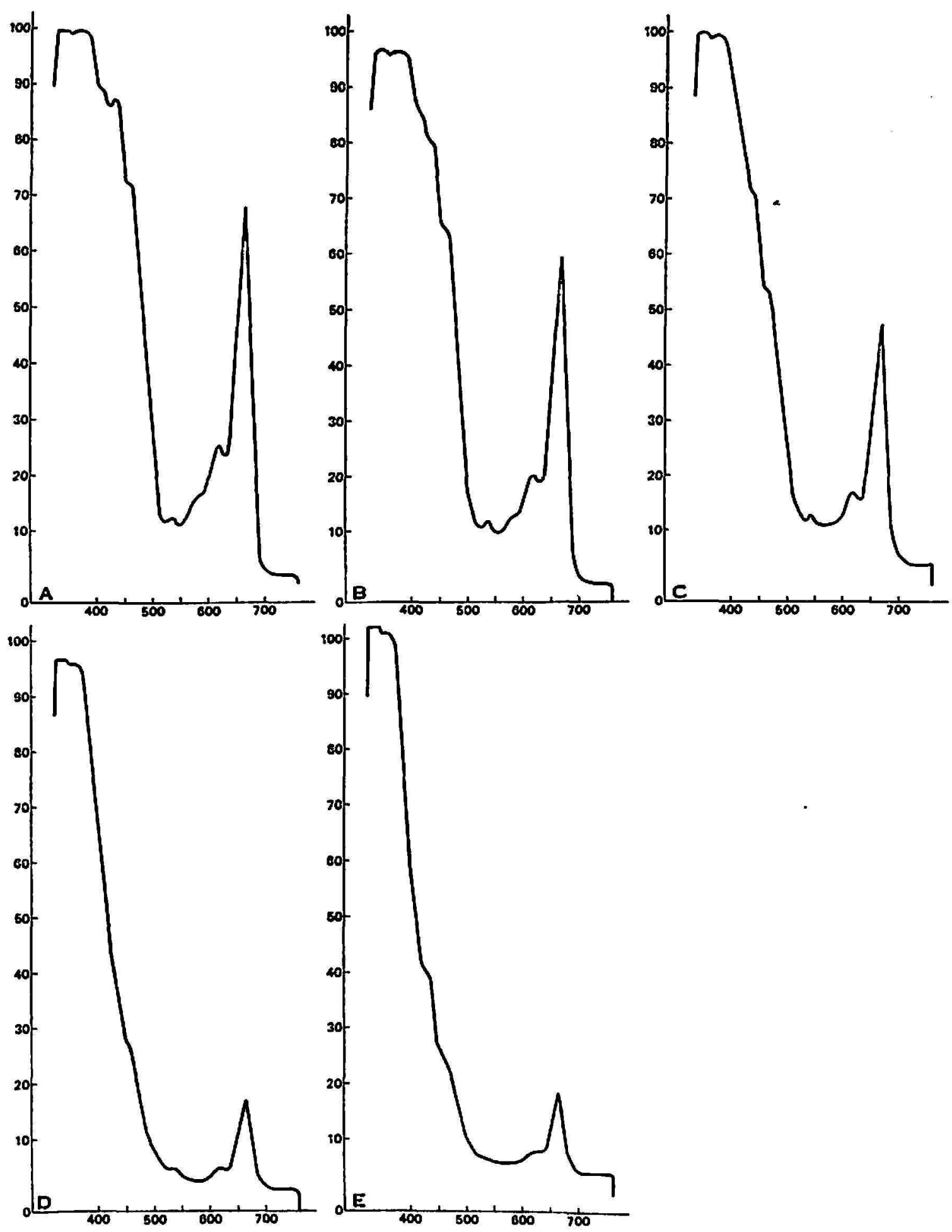

Fig. 2.-Relative chlorophyll content measured in citron of different maturity levels. Spectrum of second layer. 

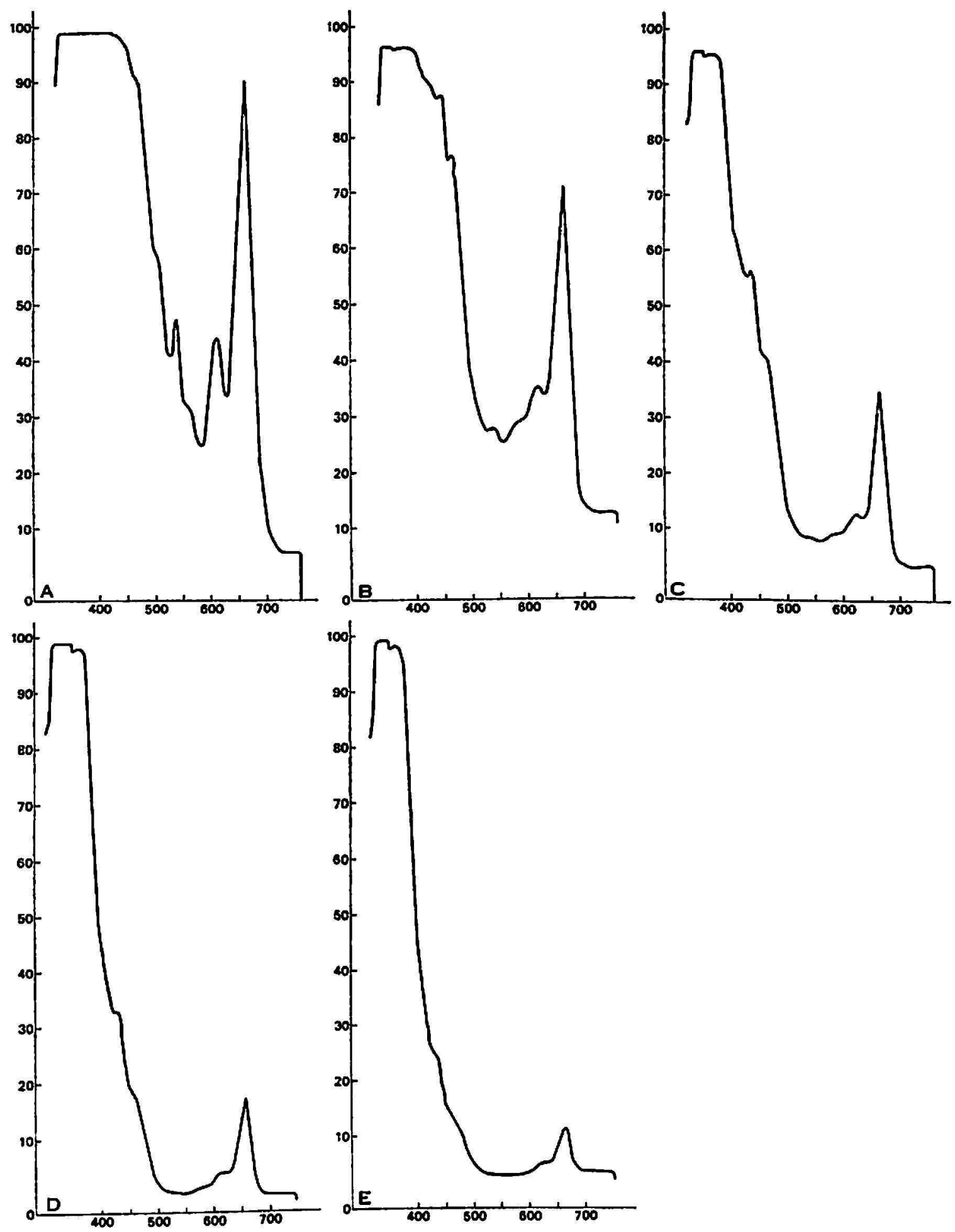

Fig. 3.-Relative chlorophyll content measured at 1/16-inch depth layers of the mature-green citron. Spectrum for first layer shows half of the chlorophyll concentration. 
TABLE 1.-Spectrophotometric determination of chlorophyll distribution in citron (Citrus medica L.) at different stages of maturity

\begin{tabular}{|c|c|c|c|c|c|c|c|c|c|c|c|c|}
\hline \multirow{2}{*}{ Layer } & \multirow{2}{*}{\multicolumn{2}{|c|}{$\begin{array}{l}\text { Amount of tissue } \\
\text { removed from fruit } \\
\text { up to this layer } \\
\text { Percent/weight }\end{array}$}} & \multicolumn{10}{|c|}{ Specific absorption coefficients at- } \\
\hline & & & & $\mathbf{m} \mu$ & & $\mathrm{m} \mu$ & $560 \mathrm{~m} \mu$ & & $35 \mathrm{~m} \mu$ & $475 \mathrm{~m} \mu$ & $460 \mathrm{~m} \mu$ & $430 \mathrm{~m} \mu$ \\
\hline \multirow{2}{*}{ Number } & \multicolumn{2}{|c|}{ Percent } & \multicolumn{2}{|c|}{ Units } & \multicolumn{2}{|c|}{ Units } & \multirow{2}{*}{ Units } & \multicolumn{2}{|c|}{ Units } & \multirow{2}{*}{ Units } & \multirow{2}{*}{ Units } & \multirow{2}{*}{ Units } \\
\hline & Average & Range & Average & Range & Average & Range & & Average & Range & & & \\
\hline \multicolumn{13}{|c|}{ Immature green } \\
\hline 1 & 11.6 & $(11-12)$ & 177.8 & $(170-184)$ & 9.4 & $(5-12)$ & $\mathbf{S}$ & 7.9 & $(6-10)$ & $\mathbf{S}$ & $\mathrm{S}$ & $\mathbf{S}$ \\
\hline 2 & 21.6 & $(21-22)$ & 66.0 & $(59-74)$ & 1.4 & $(1.3-1.6)$ & $\mathrm{s}$ & 1.4 & $(1.0-2.0)$ & $\mathrm{S}$ & $\mathbf{S}$ & $\mathbf{S}$ \\
\hline 3 & 31.3 & $(31-32)$ & 34.8 & $(30-43)$ & 1.0 & $(0.8-1.1)$ & $\mathrm{S}$ & $\mathbf{S}$ & & - & $\mathrm{S}$ & $\mathbf{S}$ \\
\hline 4 & 42.0 & $(40-43)$ & 16.8 & (14-19) & $\mathbf{S}$ & & - & $\mathbf{S}$ & & - & $\mathbf{S}$ & $\mathbf{S}$ \\
\hline 5 & 51.3 & $(47-53)$ & 7.0 & $(5-8)$ & $\mathrm{S}$ & 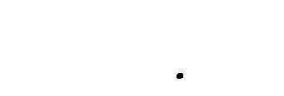 & - & $\mathrm{S}$ & & - & $\mathbf{S}$ & $\mathbf{S}$ \\
\hline \multicolumn{13}{|c|}{ Mature green } \\
\hline 1 & 8.0 & $(8-8)$ & 161.6 & (144-172) & 10.9 & $(9-14)$ & $\mathbf{S}$ & 7.0 & $(6.8)$ & $\mathbf{S}$ & $\mathbf{S}$ & $\mathbf{S}$ \\
\hline 2 & 16.7 & $(16-17)$ & 55.8 & $(45-60)$ & 1.4 & $(1.0-1.6)$ & - & 1.2 & $(1.0-1.6)$ & $\mathbf{S}$ & $\mathbf{S}$ & $\mathbf{S}$ \\
\hline 3 & 25.0 & $(25-25)$ & 24.9 & $(15-30)$ & $\mathbf{S}$ & & - & $\mathbf{S}$ & & $\mathbf{S}$ & $\mathbf{S}$ & $\mathbf{S}$ \\
\hline 4 & 32.7 & $(32-33)$ & 10.7 & $(7-17)$ & $\mathbf{S}$ & & - & $\mathbf{S}$ & & - & $\mathbf{S}$ & $\mathbf{S}$ \\
\hline 5 & 39.7 & $(38-41)$ & 4.0 & $(3-8)$ & $\mathbf{S}$ & & - & $\mathbf{S}$ & & - & $\mathbf{S}$ & $\mathbf{S}$ \\
\hline \multicolumn{13}{|c|}{ Turning ripe } \\
\hline 1 & 6.0 & $(5-7)$ & 103.6 & $(96-120)$ & 3.1 & $(3-6)$ & $\mathbf{S}$ & 2.6 & $(2.5-2.7)$ & $\mathbf{S}$ & S & $0.7(0-1.4)$ \\
\hline 2 & 13.0 & $(12-14)$ & 29.3 & $(17-42)$ & 0.8 & $(0.5-1.0)$ & $\mathbf{S}$ & 0.3 & $(0-0.5)$ & - & S & $0.3(0-0.5)$ \\
\hline 3 & 19.7 & $(19-20)$ & 9.2 & $(5-14)$ & 0.3 & $(0-0.5)$ & - & $\mathbf{S}$ & & - & $\mathbf{S}$ & $\mathrm{s}$ \\
\hline 4 & 25.5 & $(24-27)$ & 4.3 & $(3-6)$ & $\mathbf{S}$ & & - & - & . & - & $\mathrm{S}$ & $\mathrm{S}$ \\
\hline 5 & 31.0 & $(30-33)$ & 2.0 & $(1-3)$ & $\mathbf{S}$ & & - & - & & - & $\mathbf{S}$ & $\mathbf{S}$ \\
\hline
\end{tabular}


Ripe

\begin{tabular}{|c|c|c|c|c|c|c|c|c|c|c|c|c|}
\hline 1 & $\mathbf{5 . 0}$ & $(5-10)$ & 42.4 & $(38-46)$ & 1.5 & $(1-2)$ & $\mathrm{S}$ & 0.3 & $(0-0.5)$ & $\mathbf{S}$ & - & - \\
\hline 2 & 11.0 & $(10-12)$ & 17.3 & (15-19) & 0.8 & $(0.5-1.0)$ & - & $\mathbf{S}$ & & $\mathbf{S}$ & - & $\mathbf{S}$ \\
\hline 3 & 17.0 & $(15-19)$ & 8.8 & $(5-13)$ & $\mathbf{S}$ & & - & - & & - & - & $\mathbf{S}$ \\
\hline 4 & 22.5 & $(21-24)$ & 4.7 & $(2-8)$ & $\mathbf{S}$ & & - & - & & $\mathbf{S}$ & - & - \\
\hline 5 & 27.5 & $(25-30)$ & 4.3 & $(2-7)$ & $\mathbf{S}$ & & - & - & & - & - & - \\
\hline
\end{tabular}


the original amount. The spectrophotometric curve was determined for sample from 760 to $320 \mathrm{~m} \mu$ in a Beckman DBG instrument.

\section{RESULTS AND DISCUSSION}

As stated by Aronoff (1), any of the properties of chlorophyll may be used for analytical purposes (e.g., $\mathrm{Mg}, \mathrm{N}$ content, optical activity, etc.). For chlorophyll determinations, one of the easiest and most sensitive properties to measure is the color of the pigments. The usual analytical methods employed are colorimetric, spectrophotometric or fluorescent. Although the latter method is the most sensitive by far of the three, the first two are used most commonly and in general sufficiently sensitive for all purposes.

Spectrophotometric studies carried out in the visible spectrum for the pigments found in the citron peel suggest the presence of chlorophyll $a$. The absorption spectra of the acetone extracts of citron peel (figs. 2 and 3) correspond to those given by Aronoff (1) and Bogorad (2) for chlorophyll $a$.

Because of the unique absorption of the chlorophylls in the red region of the spectrum, it is possible to measure plant extracts of chlorophyll in the presence of carotenoids. Such measurements have been made by Petering et al. $(5,6)$. Spectrophotometric determinations of extracts in the 660 to $680 \mathrm{~m} \mu$ region of the spectrum, which characterizes the red maxima of chlorophyll $a$, are used to measure the amount of this compound. In our study, the clearly defined maxima at $665 \mathrm{~m} \mu$ in all the spectra obtained give a relative quantitative determination of the amount of chlorophyll $a$ in the citron.

Figures 2, A to 2, E show the spectra of chlorophyll $a$ in the mesocarp of citrons at different maturity levels. The second layer of fruits which were immature, mature green, and turning ripe was used for these measurements, because the spectra of the extracts of the first layer could not be measured without dilution. The spectra of this layer went off the instrument scale; maximum peaks masked most minor peaks thus producing a curve of no analytical value.

The results of the spectrophotometric study show that there is no increase in the carotenoid content of the epicarp and mesocarp of the citron. The yellowish color in the tissues of ripe citron is the result of the expected chlorophyll destruction that takes place during the ripening process, thus unmasking the small amount of yellow carotenoids and flavonoids present (3).

Figures 3, A to 3, E show the spectra of chlorophyll in the epicarp and in different layers of the mesocarp of the mature green citron. Spectrum in figure 3, A corresponds to the first layer of citron tissue, which includes the epicarp and a certain amount of mesocarp. Due to the high concentration of pigment in the acetone extract of this layer, it was diluted volumetrically 
(1:1 dilution) to obtain a readable spectrum. The concentration of chlorophyll represented by the peak at $665 \mathrm{~m} \mu$ is only half the actual concentration found in the extract as shown by data presented in table 1, which gives a numerically quantitative picture of the variation in the chlorophyll content of the citron peel at different depths in the mesocarp tissue.

The variation in chlorophyll content in the mesocarp of the citron fruit is important because the green color in this tissue will provide the grcenness in the candied product. This study suggests the need of processing citrons at various stages of maturity from immature to mature green. It is at these levels that the mesocarp contains the greatest amount of chlorophyll and the chlorophyll pigment goes deeper into the fruit.

\section{SUMMARY}

The variation in the chlorophyll content of citrons was determined at different stages of maturity and at different depths in the mature green fruit.

Fruit at different stages of maturity (immature green, mature green, turning ripe, and ripe) was selected from a commercial farm in Adjuntas, Puerto Rico. An examination of the endocarp revealed that it was of a greenish tint in the immature green fruit, greenish yellow in the mature green, completely yellow in the turning ripe, and whitish yellow or cream in the fully ripe fruit.

Spectrophotometric determinations were made at different depths of the fruit, showing that the chlorophyll content was highest in the immature green fruit, with the mature green following closely. The chlorophyll content of fruit turning ripe was substantially lower than in the first two stages of maturity but higher than in the ripe fruit. The chlorophyll content of the citron diminishes considerably from one tissue layer to another as one cuts deeper into the fruit. Nevertheless, tissues of immature and mature green fruit contain a good amount of green pigment at greater depths. Because greenness is a characteristic index of quality in candied citron, it is advisable to use immature and mature green fruit for this purpose.

\section{RESUMEN}

Las variaciones en el contenido de clorofila se determinaron en cidras de diferentes estados de madurez y en el tejido de la fruta cortado a diferentes profundidades. La fruta se obtuvo en una finca comercial de Adjuntas, Puerto Rico, siendo las muestras representativas de cuatro estados de madurez: frutas nuevas, hechas pero aún con la cáscara verde, pintonas y maduras. Al examinar el endocarpio de las diferentes frutas se encontró que las nuevas tenían el tejido de un color verdoso, las hechas pero aún con la cáscara verde de un color verde-amarillo, las pintonas de un color amarillo y las maduras de un amarillo blancuzco, casi crema.

El trabajo espectrofotométrico se llevó a cabo tomando muestras representativas a diferentes niveles de profundidad en la fruta. Los resultados demostraron que las 
cidras nuevas tienen el contenido más elevado de clorofila siguiéndolas de cerca las frutas hechas pero aún con la cáscara verde. El contenido en la fruta pintona es muchísimo más bajo que en la nueva y verde, pero mucho más elevado que en la madura. Los datos obtenidos indican también que el contenido de clorofila disminuye segán se penetra en el mesocarpio de la fruta. Sin embargo, en las capas más profundas de la fruta nueva y de la hecha pero aún con la cáscara verde se encuentra un contenido más elevado en pigmento verde. Dado el caso de que la coloración verde en la cidra curada y endulzada es un índice de calidad, es aconsejable cosechar y fermentar la fruta nueva o la fruta ya hecha pero aún de cáscara verde.

\section{LITERATURE CITED}

1. Aronoff, S., The chemistry of chlorophyll, pp. 134-79, Advances in food research, Vol. 14, edited by Mrak, E. M. and Stewart, G. F., Academic Press Inc., New York, N.Y., 1956.

2. Bogorad, L., Porphyrins and bile pigments, pp. 724-25, Plant biochemistry, edited by Bonner, J. and Varner, J. E., Academic Press, Inc., New York, N.Y., 1965.

3. Mackinney, G., Coloring matters, chapt. 10, p. 304, The orange-its biochemistry and physiology, edited by Sinclair, W. B., University of California Printing Department, Univ. Calif., Berkeley, Calif., 1961.

4. - Coloring matters, chapt. 10, pp. 317-20, The orange-its biochemistry and physiology, edited by Sinclair, W. B., University of California Printing Department, Univ. Calif., Berkeley, Calif., 1961.

5. Petering, H. G., Benne, E. J., and Morgal, P. W., Determination of chlorophyll and carotene, Ind. Eng. Chem., Anal. Ed. 13: 236, 1941.

6. 一, Wolman, W., and Hibbard, R. P., Determination of chlorophyll and carotene in plant tissue, Ind. Eng. Chem., Anal. Ed. 12: 148-51, 1940.

7. Spencer, M., Fruit ripening, chapt. 30, p. 810, Plant biochemistry, edited by Bonner, J. and Varner, J. E., Academic Press Inc., 111 Fifth Avenue, New York, N.Y. 10003.

8. Ting, S. W., and Hendrickson, R., Natural color enhancers-Orange peel carotenoids for orange juice products, Food Technol. 23(7): 87-90, 1969.

9. Willard, H. H., Lynne, L. M., and Dean, J. A., Instrumental methods of analysis, 4th. ed., p. 80, D. VanNostrand Co. Inc., Princeton, N.J., 1965. 